\title{
Synergistic activity of activin A and basic fibroblast growth factor on tyrosine hydroxylase expression through Smad3 and ERK1/ERK2 MAPK signaling pathways
}

\author{
Y L Bao, K Tsuchida, B Liu ${ }^{1}$, A Kurisaki, T Matsuzaki \\ and $\mathbf{H}$ Sugino \\ Institute for Enzyme Research, University of Tokushima, 3-18-15 Kuramoto, Tokushima 770-8503, Japan \\ ${ }^{1}$ Department of Hand Surgery, China-Japan Union Hospital of Jilin University, 126 Xiantai St, Changchun 130031, China \\ (Requests for offprints should be addressed to K Tsuchida; Email: tsuchida@ier.tokushima-u.ac.jp) \\ (Y L Bao is now at Institute of Genetics and Cytology, Northeast Normal University, 5268 Renmin St, Changchun 130024, China) \\ (T Matsuzaki is now at Department of Biology, Faculty of Sciences, Kyushu University Graduate School, Fukuoka 812-8581, Japan)
}

\begin{abstract}
Activin has previously been shown to act as a nerve cell survival factor and to have neurotrophic effects on neurons. However, the role of activin in regulating neurotransmitter expression in the central nervous system and the exact mechanisms involved in this process are poorly understood. In the present study, we report that activin A and basic fibroblast growth factor (bFGF) synergistically increased the protein level of tyrosine hydroxylase $(\mathrm{TH})$, and also greatly increased the TH mRNA level, in both mouse E14 striatal primary cell cultures and the hippocampal neuronal cell line HT22. Activin A and bFGF
\end{abstract}

cooperatively stimulated nuclear translocation of Smad3 and specifically activated ERK1/2, but not p38 or JNK. Interestingly, a specific inhibitor for MEK, U0126, efficiently blocked the induction of $\mathrm{TH}$ promoter activity by activin A and bFGF, indicating that activin A collaborated with $\mathrm{bFGF}$ signaling to induce the $\mathrm{TH}$ gene through selective activation of ERK-type MAP kinase in mouse striatal and HT22 cells. These data suggest that activin A may act in concert with bFGF for the development of TH-positive neurons.

Journal of Endocrinology (2005) 184, 493-504

\section{Introduction}

Parkinson's disease is a very common neurodegenerative disorder (Gudmundsson 1967), characterized by akinesia, rigidity and tremor, that is related to the loss of dopaminergic (DA) neurons in the substantia nigra and depletion of dopamine in the striatum (Ehringer \& Hornykiewicz 1960). Tyrosine hydroxylase (TH) is the first and major rate-limiting enzyme of catecholamine biosynthesis in DA and noradrenergic neurons (Nagatsu et al. 1964). Therefore, studies on the transcriptional regulation of $\mathrm{TH}$ are very important for understanding the development of DA neurons.

Fibroblast growth factor (FGF) is an important modulator of the cell growth and differentiation of various cells, including neurons. Basic FGF (bFGF) promotes survival and stimulates the neurite-promoting activity of embryonic DA neurons in the substantia nigra (Grothe et al. 2000). Recent research has revealed that all three bFGF isoforms and FGF receptors 1-3 are expressed in both the striatum and substantia nigra (Claus et al. 2004). Furthermore, bFGF produces the recovery of motor behavior, dopamine metabolite levels, striatal F-DOPA uptake and TH-positive cells in hemiparkinsonian monkeys (Fontan et al. 2002).

Activin A, a member of the transforming growth factor (TGF)- $\beta$ superfamily, has various effects on diverse biologic systems, such as erythroid differentiation, mesoderm induction in Xenopus embryos, bone growth and somatostatin induction (Mathews 1994, Tsuchida 2004). In addition, activin acts as a nerve cell survival factor (Schubert 1990) and has neurotrophic effects on nerve cells (Fann \& Patterson 1994a,b, Hughes et al. 1999). Furthermore, activin A mRNA is expressed in the striatum during embryogenesis from E16-E17 (Roberts et al. 1991). Activin receptors are widely expressed in the adult rat brain, and their expression is upregulated in response to brain injury (Cameron et al. 1994, Funaba et al. 1997, Lewen et al. 1997).

Since activin A, bFGF and their receptors are expressed by a subpopulation of the ventricular zone progenitors, both activin and bFGF could exert their actions locally. However, the role of these factors in regulating the expression of catecholamine neurotransmitters and the 

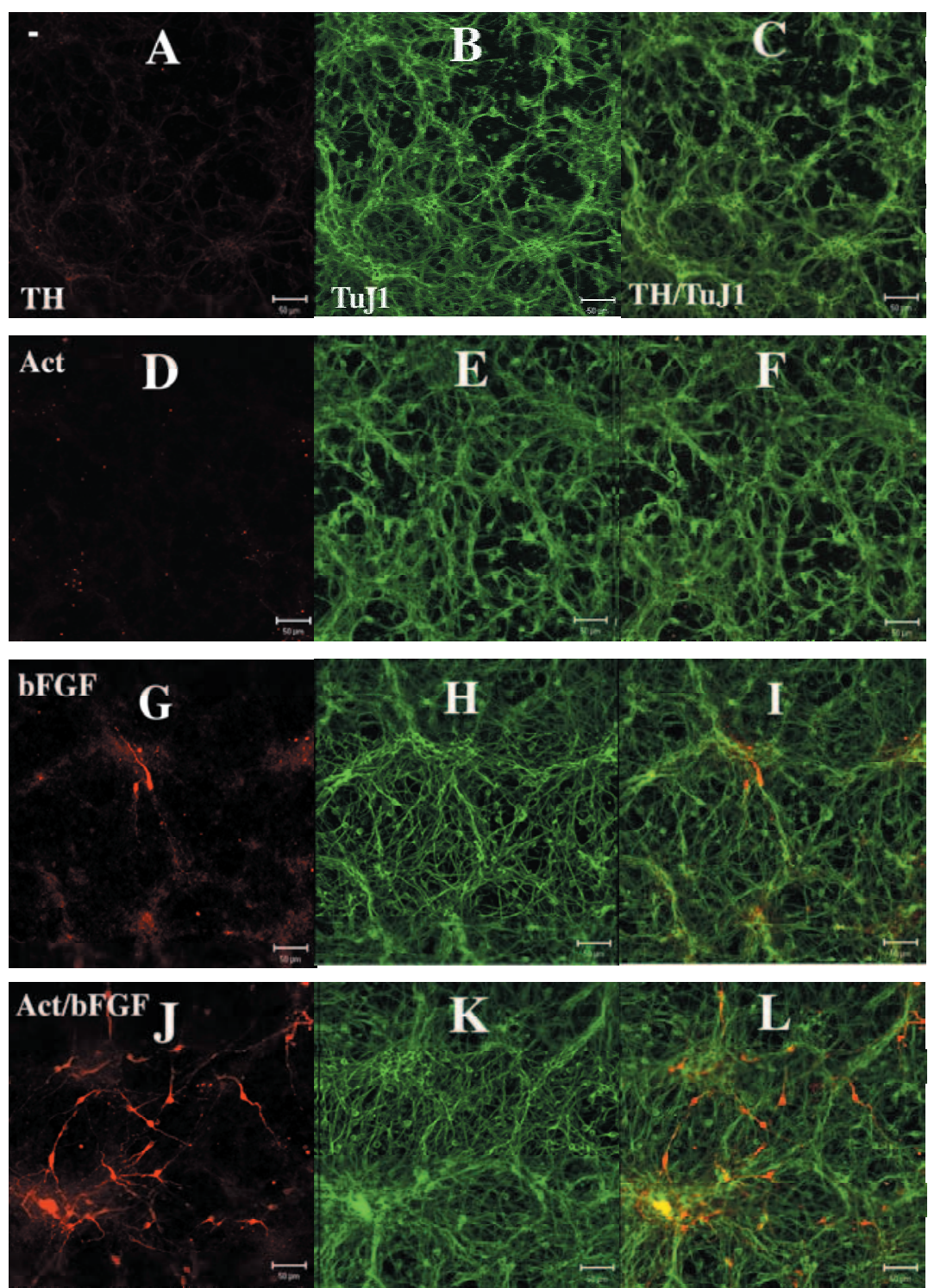

Figure 1 Activin A and bFGF induce TH immunoreactivity in E14 striatal cells. E14 striatal cells were dissociated and cultured $\left(1 \times 10^{6}\right.$ cells $\left./ \mathrm{ml}\right)$ on poly-L-ornithine $(15 \mu \mathrm{g} / \mathrm{ml}) /$ fibronectin $(1 \mu \mathrm{g} / \mathrm{ml})$-coated glass cover slips in medium alone or medium containing activin A (100 ng/ml), bFGF $(20 \mathrm{ng} / \mathrm{ml})$ or both for $72 \mathrm{~h}$. Fixed cells were processed for dual labeling with a monoclonal antibody against TuJ 1 and a polyclonal antibody against $\mathrm{TH}$, followed by FITC-conjugated antimouse IgG and rhodamine-conjugated antirabbit IgG secondary antibodies. TH (red), TuJ1 (green) and their merged images are indicated. (A-C) Control; (D-F) activin A alone; (G-I) bFGF alone; (J-L) activin A and bFGF. Scale bars $=50 \mu \mathrm{m}$.

molecular mechanisms involved in this process are not fully understood. Elucidating the mechanism of differentiation of TH-positive neurons in the striatum could provide insights for more effective therapeutic approaches for Parkinson's disease.
In the present study, we examined the synergistic effects of activin A and bFGF on TH expression in mouse E 14 striatal and HT22 cells. We further investigated the potential molecular mechanisms underlying the synergistic effects of these factors. 
Table 1 Effect of activin A and bFGF on the induction of TH-positive cells in E14 striatal cells. E14 striatal cells $\left(1 \times 10^{6} / \mathrm{ml}\right)$ were treated with the indicated factors (activin A, $100 \mathrm{ng} / \mathrm{ml}$; bFGF, $20 \mathrm{ng} / \mathrm{ml}$ ) and stained as described in the legend for Fig. 1. The numbers of TuJ1-postive cells (TuJ1) and TH-positive cells $(\mathrm{TH})$ were counted at $\times 100$ magnification in four randomly chosen fields

\begin{tabular}{|c|c|c|c|}
\hline & TH-IR & TuJ1-IR & TH/TuJ1-IR (\%) \\
\hline \multicolumn{4}{|l|}{ Growth factors } \\
\hline None & 0 & 1448 & 0 \\
\hline Acitvin A & 0 & 1329 & 0 \\
\hline bFGF & 8 & 1694 & $0 \cdot 5$ \\
\hline Activin $\mathrm{A}+\mathrm{bFGF}$ & 144 & 1721 & $8 \cdot 4$ \\
\hline
\end{tabular}

\section{Materials and Methods}

\section{Cell culture}

Pregnant C57BL/6 mice at gestational day 14 were anesthetized with diethyl ether and exsanguinated. Embryos were removed and placed in a Petri dish containing Hanks' balanced salt solution (HBSS). After decapitation, the brain was removed and the striatum was microdissected out, carefully triturated with a fire-polished Pasteur pipette to produce a single cell suspension and then plated at a density of $1 \times 10^{6}$ cells $/ \mathrm{ml}$ on poly-L-ornithine $(15 \mu \mathrm{g} /$ $\mathrm{ml}) /$ fibronectin $(1 \mu \mathrm{g} / \mathrm{ml})$-coated tissue culture plates or slides. The culture medium was the serum-free, chemically defined Dulbecco's Modified Eagle's Medium (DMEM)/F12 (1:1) containing glucose (1000 mg/l), glutamine $(2 \mathrm{mM})$, sodium bicarbonate $(3 \mathrm{mM})$ and HEPES buffer $(5 \mathrm{mM})$. A defined hormone mixture containing insulin $(25 \mu \mathrm{g} / \mathrm{ml})$, transferrin $(100 \mu \mathrm{g} / \mathrm{ml})$, progesterone $(20 \mathrm{nM})$, putrescine $(100 \mu \mathrm{M})$ and selenium chloride $(30 \mathrm{nM})$ was included in the medium. At $2 \mathrm{~h}$ after plating, activin $\mathrm{A}$ and/or bFGF were added to the cultures. Cells were incubated at $37{ }^{\circ} \mathrm{C}$ with $5 \% \mathrm{CO}_{2}$. All tissue culture reagents were purchased from Sigma, except for glutamine (Invitrogen). The mouse hippocampal neuronal cell line HT22 was maintained in DMEM supplemented with 10\% fetal bovine serum and antibiotics $(100 \mathrm{U} / \mathrm{ml}$ penicillin and $100 \mu \mathrm{g} / \mathrm{ml}$ streptomycin; Wako, Osaka, Japan).

\section{Antibodies}

A mouse monoclonal antibody against $\beta$-tubulin type III $(\mathrm{TuJ} 1)$ was purchased from Sigma, and a rabbit polyclonal antibody against TH was obtained from Chemicon (Temecula, CA, USA). MAPK antibody kits (containing polyclonal antibodies against phospho-p38, phosphoJNK/SAPK and phospho-p44/p42), antibodies against Smad3 and Smad4, and a mouse monoclonal antibody against PCNA were from Cell Signaling Technology Inc (Beverly, MA, USA).

\section{Indirect immunocytochemistry}

Mouse striatal and HT22 cells were plated on glass cover slips in 12-well tissue culture plates. Cells were fixed with 4\% paraformaldehyde in PBS for $30 \mathrm{~min}$ at room temperature, washed three times with PBS and permeabilized in ice-cold methanol for $20 \mathrm{~min}$. The cells were then blocked with $1 \%$ bovine serum albumin (BSA) in PBS for $1 \mathrm{~h}$, and double-immunostained with the rabbit anti-TH antibody $(1: 300)$ and mouse anti-TuJ1 antibody (1:300) overnight at $4{ }^{\circ} \mathrm{C}$. Subsequently, the cells were incubated with rhodamine-conjugated rat serum-absorbed goat antirabbit immunoglobulin (Ig) G (1:200) and FITCconjugated rabbit antimouse $\operatorname{IgG}(1: 200)$ at $4{ }^{\circ} \mathrm{C}$ for $2 \mathrm{~h}$. Fluorescent images were visualized and captured with a confocal microscope (Zeiss).

\section{RT-PCR and Northern blotting}

Total RNA was extracted with the TRIzol reagent, according to the manufacturer's protocol (Invitrogen). The concentration and purity of the extracted RNA were measured with the optical densities at 260 and $280 \mathrm{~nm}$. cDNA was prepared with SUPERSCRIPT II reverse transcriptase (Invitrogen). The following primers were used to amplify the target genes:

- GAPDH: 5'-ACCACAGTCCATGCCATCAC-3', 5'-TCCACCACCCTGTTGCTGTA-3'

- TH: 5'-CCTCCTTGTCTCGGGCTGTAA-3’, 5'-CTGAGCTTGTCCTTGGCGTCA-3'

- aromatic L-amino acid decarboxylase (AADC): 5'-CCTACTGGCTGCTCGGACTAA-3', 5'-GCGTA CCAGGGACTCAAACTC-3'

dopamine $\beta$-hydroxylase (DBH): $5^{\prime}$-GTGACCAG AAAGGGCAGATCC-3', 5'-CACCGGCTTCTTCTG GGTAGT-3'

- $\beta$-actin: 5'-CTGAAGTACCCCATTGAACATG GC-3', 5'-CAGAGCAGTAATCTCCTTCTGCAT-3'.

PCR was performed for 30 cycles, with each cycle consisting of $94{ }^{\circ} \mathrm{C}$ for $45 \mathrm{~s}, 62{ }^{\circ} \mathrm{C}$ for $30 \mathrm{~s}$ and $72{ }^{\circ} \mathrm{C}$ for $45 \mathrm{~s}$, followed by a final extension step at $72{ }^{\circ} \mathrm{C}$ for $10 \mathrm{~min}$. The amplified PCR products were subjected to $2 \%$ agarose gel electrophoresis and stained with ethidium bromide. The specific bands were quantified with NIH Image1.62 software (NIH, Bethesda, MD, USA). For Northern blotting, $27.5 \mu \mathrm{g}$ total RNAs isolated from striatal cultured cells were fractionated and blotted onto a nylon membrane. A cDNA fragment of mouse $\mathrm{TH}$ generated by RT-PCR was used as a probe. Hybridization, washing, and detection were performed as described previously (Shoji et al. 2000).

\section{Construction of plasmids}

The $4.5 \mathrm{~kb}$ and $948 \mathrm{bp}$ upstream sequences of the rat $\mathrm{TH}$ gene (kindly provided by Dr D Chikaraishi) were 
(A)
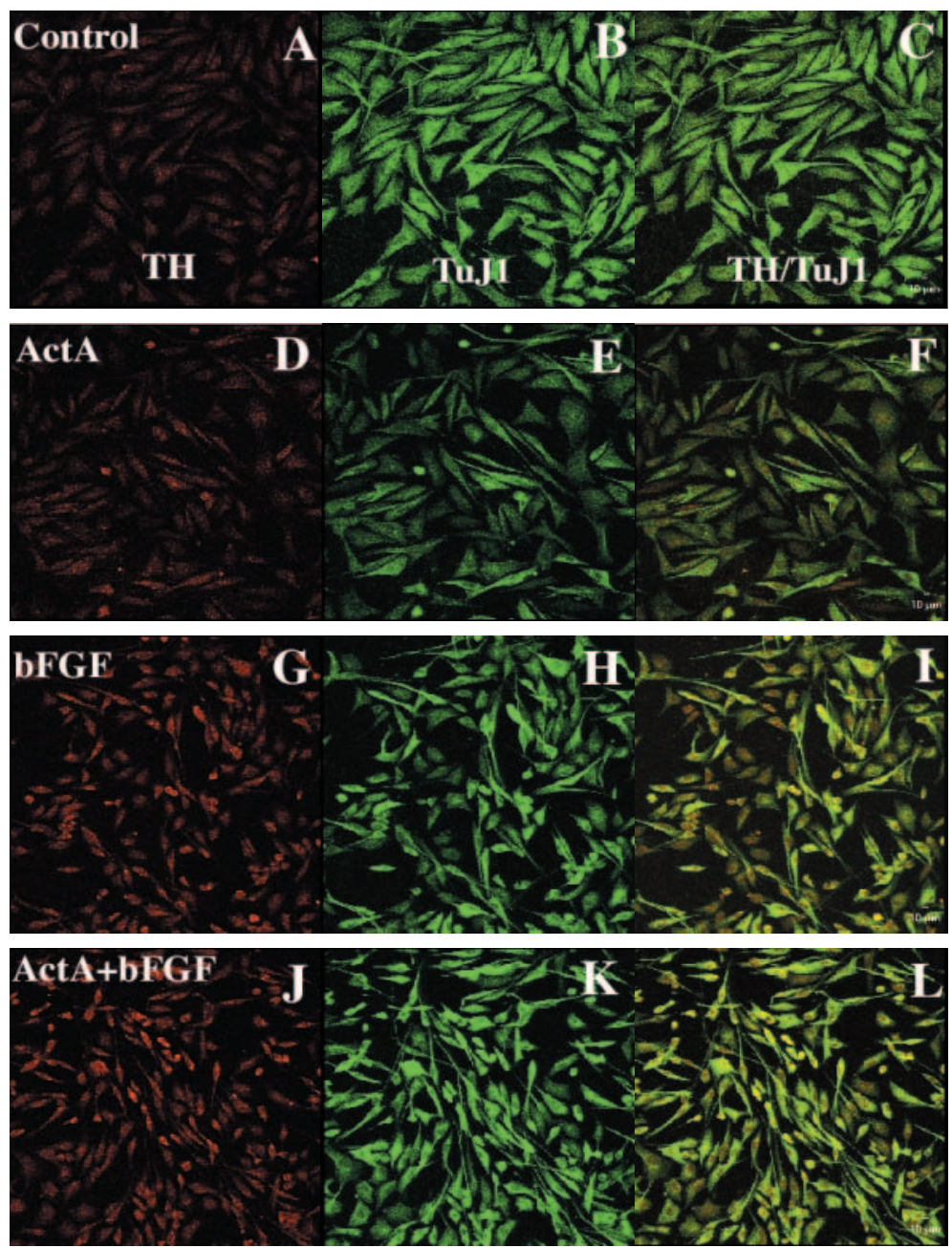

(B)
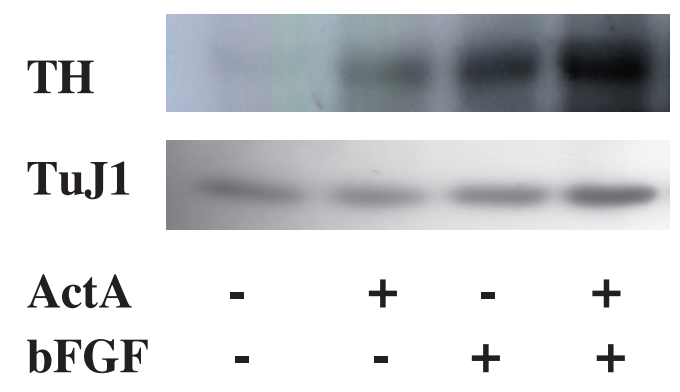

(C)

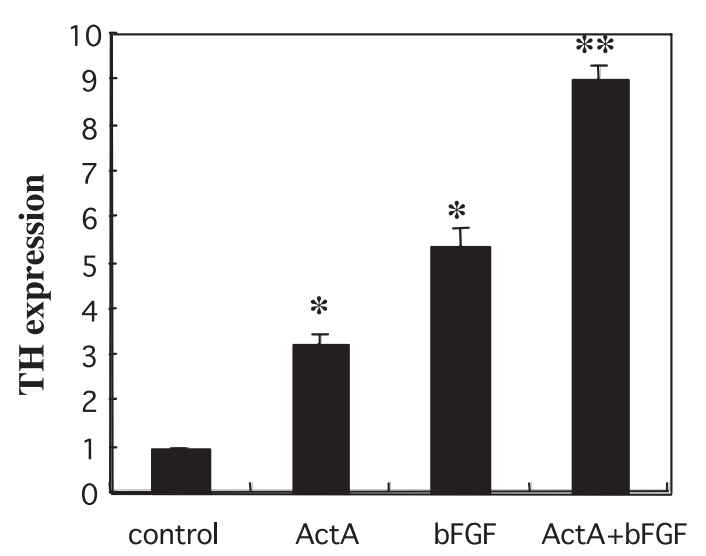

www.endocrinology-journals.org 
subcloned into the SmaI and KpnI/SmaI sites of the pGL2 vector (Promega) to generate the TH-4.5 kb-luc and TH-948 bp-luc reporters respectively.

\section{Luciferase assay}

HT22 cells were plated at $1 \times 10^{5}$ cells/well in 24-well plates, and transfected with the Transfast reagent (Promega). At $24 \mathrm{~h}$ after transfection, the cells were treated with or without activin A and/or bFGF for $12 \mathrm{~h}$, and then extracted in buffer $(25 \mathrm{mM}$ glycylglycine, $\mathrm{pH}$ $7 \cdot 8,15 \mathrm{mM} \mathrm{MgSO}, 4 \mathrm{mM}$ EGTA and 1\% Triton $\mathrm{X}-100)$. The luciferase activity was measured and normalized to the $\beta$-galactosidase activity, as described previously (Shoji et al. 2000).

\section{Preparation of cytosolic and nuclear extracts}

Mouse striatal primary cell cultures and HT22 cells exposed to activin A and/or bFGF were washed twice with cold PBS, and incubated in $100 \mu$ hypotonic buffer (20 mM HEPES-NaOH (pH 7.9), 1 mM EDTA, 0.5\% $\mathrm{NP}-40,2 \mu \mathrm{g} / \mathrm{ml}$ leupeptin, $2 \mu \mathrm{g} / \mathrm{ml}$ pepstatin, $2 \mu \mathrm{g} / \mathrm{ml}$ aprotinin, $4 \mathrm{mM}$ PMSF, $1 \mathrm{mM}$ EGTA and $1 \mathrm{mM} \mathrm{NaF}$ ). Each lysate was kept on ice for $10 \mathrm{~min}$ and centrifuged at 5000 r.p.m. for $2 \mathrm{~min}$. The supernatant was then collected as the cytosolic fraction. The pellet was incubated on ice for $20 \mathrm{~min}$ in $30 \mu \mathrm{l}$ high-salt buffer (hypotonic buffer supplemented with $420 \mathrm{mM} \mathrm{NaCl}$ and $20 \%$ glycerol) and centrifuged at 15000 r.p.m. for $5 \mathrm{~min}$. The supernatant was then collected as the nuclear fraction. The protein concentration was determined by a colorimetric assay using a DC protein assay kit (Bio-Rad). Equal amounts of cytosolic proteins and an equivalent amount of nuclear proteins were electrophoresed in a 12\% SDS-PAGE gel, and analyzed by Western blotting.

\section{Western blotting analysis}

Proteins resolved by SDS-PAGE were transferred to PVDF membranes, and blocked with 5\% nonfat dry milk

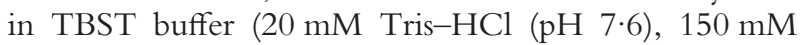
$\mathrm{NaCl}$ and $0 \cdot 05 \%$ Tween 20) for $1 \mathrm{~h}$ at room temperature. The membranes were then probed with 1000-fold diluted primary antibodies in $1 \%$ milk/TBST for $12 \mathrm{~h}$ at room temperature, washed three times, incubated with HRP-
Table 2 Effect of activin A and bFGF on the induction of TH-positive cells in HT22 cells. HT22 cells were fixed and immunostained as described in the legend for Fig. 2. The numbers of TuJ1-postive cells (TuJ1) and TH-positive cells (TH) were counted at $\times 100$ magnification in four randomly chosen fields

\begin{tabular}{|c|c|c|c|}
\hline & TH-IR & TuJ1-IR & TH/TuJ1-IR (\%) \\
\hline \multicolumn{4}{|l|}{ Growth factors } \\
\hline None & 0 & 482 & 0 \\
\hline Acitvin A & 12 & 520 & $2 \cdot 3$ \\
\hline bFGF & 96 & 536 & $17 \cdot 9$ \\
\hline Activin $A+b F G F$ & 176 & 734 & 24 \\
\hline
\end{tabular}

conjugated secondary antibodies for $1 \mathrm{~h}$ at room temperature, and washed extensively before detection by chemiluminescence with ECL-Plus (Amersham). Proteins were visualized by exposing the blots to Fuji Super RX film. Western blotting data were quantified with NIH Image $1 \cdot 61$ software.

\section{Results}

Activin $A$ and bFGF synergistically induce TH immunoreactivity in striatal primary cell cultures of mouse embryos

To investigate the effects of activin A and bFGF on TH expression, mouse primary striatal cells were cultured in the presence or absence of activin A and/or bFGF for $72 \mathrm{~h}$, followed by indirect immunofluorescence, using the rabbit anti-TH polyclonal and mouse anti-TuJ1 monoclonal antibodies. When cells were cultured without any factors, striatal progenitors did not express $\mathrm{TH}$ protein (Fig. 1A-C). Activin A alone had no effect (Fig. 1D-F), while in the presence of bFGF alone, a small number of striatal progenitors expressed TH protein (Fig. 1 G-I). However, when the two factors were combined, the number of TH-positive cells was dramatically increased $(17 \cdot 8$-fold) compared with the bFGF-treated cells (Fig. 1J-L; Table 1). These results indicate that the two growth factors synergistically increase the $\mathrm{TH}$ protein level in mouse striatal primary cell cultures.

\section{Activin $A$ and bFGF induce TH expression accompanied by morphologic changes in HT22 cells}

We further examined the effects of activin A and bFGF in the mouse hippocampal neuronal cell line HT22.

\footnotetext{
Figure 2 Activin A and bFGF induce TH immunoreactivity in HT22 cells. (A) HT22 cells $\left(1 \times 10^{5}\right)$ were plated on glass cover slips in 12 -well plates and cultured in medium alone or medium containing activin $\mathrm{A}(100 \mathrm{ng} / \mathrm{ml}), \mathrm{bFGF}(20 \mathrm{ng} / \mathrm{ml})$ or both for $48 \mathrm{~h}$ at $37^{\circ} \mathrm{C}$. Cells were then fixed and permeabilized, and double immunostaining was performed as described in the legend for Fig. 1 . TH (red), TuJ1 (green) and their merged images are indicated. (A-C) Control; (D-F) activin A alone; (G-I) bFGF alone; (J-L) activin A and bFGF. Scale bars $=10 \mu \mathrm{m}$. (B) Western blotting analysis of the synergistic effect of activin A and bFGF on TH expression in HT22 cells. HT22 cells were cultured in medium alone or medium containing activin A (100 ng/ml), bFGF $(20 \mathrm{ng} / \mathrm{ml})$ or both for $36 \mathrm{~h}$; then Western blotting was performed as described in Materials and Methods. (C) The specific bands for TH in panel B were quantified with NIH Image 1.62 software, and the signal intensity of TH was normalized by that of TuJ1. ${ }^{*} P<0 \cdot 01$ vs control; ${ }^{* *} P<0 \cdot 01$ vs activin A- or bFGF-treated cells by t-test.
} 


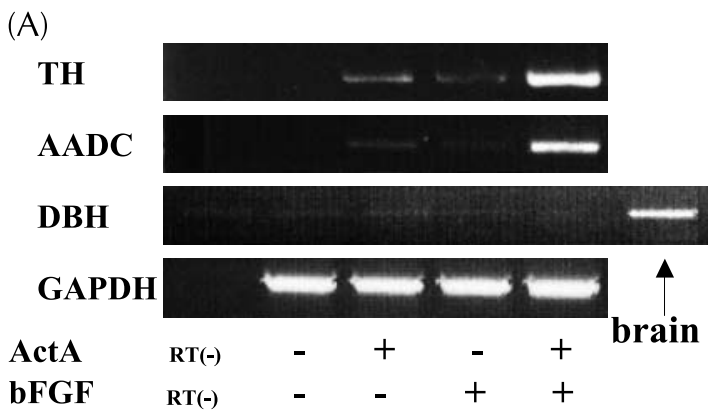

(B)

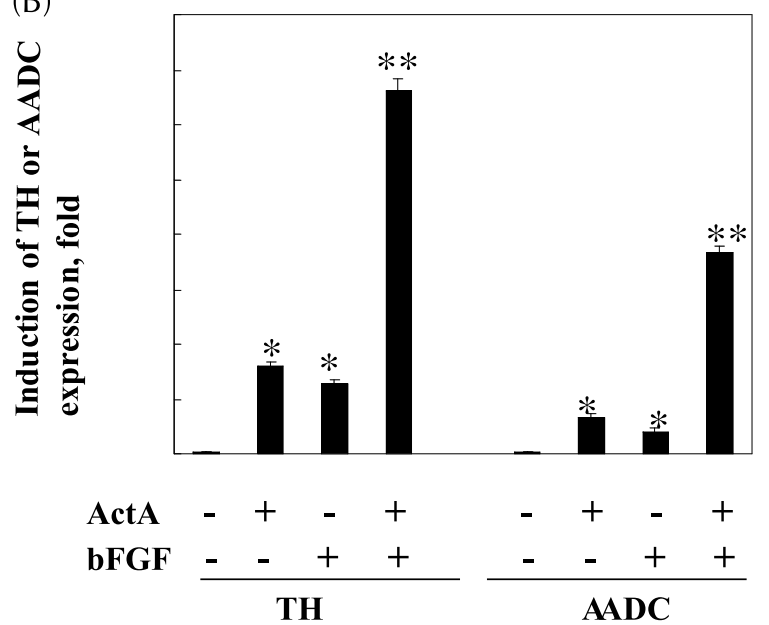

(C)

TH

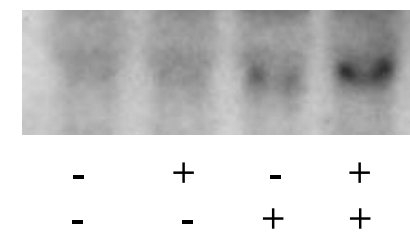

(D)

TH

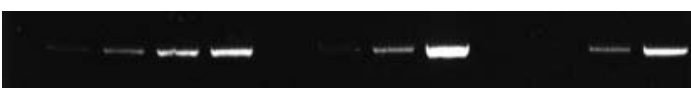

$\beta$-actin

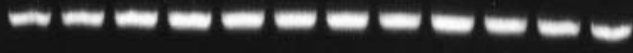

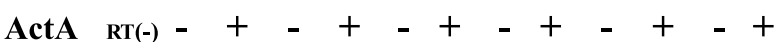

bFGF RT(-) $\frac{-++t}{6 \mathrm{~h}} \frac{--++\frac{-++}{12 \mathrm{~h}}}{24 \mathrm{~h}}$

(E)

ActA

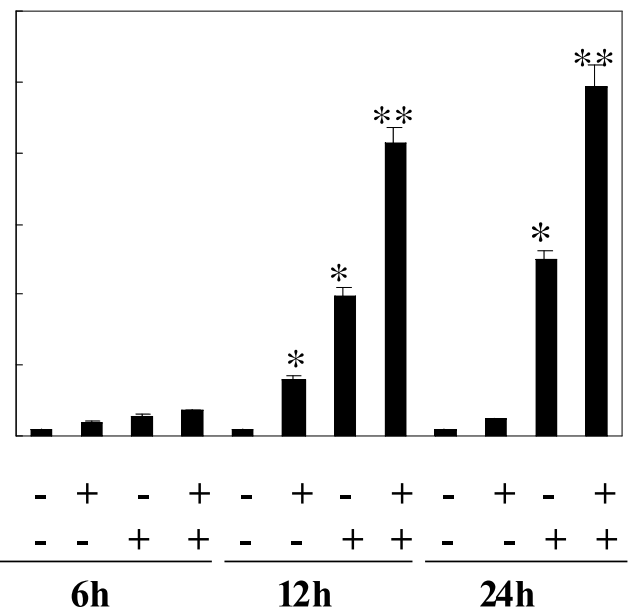

Figure 3 Expression of genes for synthesis of TH-positive neurons induced by activin A and bFGF. (A) Mouse E14 embryo striatal cells were treated with activin A $(100 \mathrm{ng} / \mathrm{ml})$, bFGF $(20 \mathrm{ng} / \mathrm{ml})$ or both for $36 \mathrm{~h}$; then RT-PCR was performed with specific primers, as described in Materials and Methods. cDNA for mouse brain mRNA was used as a positive control for DBH. (B) The specific bands in panel A were quantified with NIH Image 1.62 software, and the signal intensities of TH and AADC were normalized by that of GAPDH. (C) Northern blot analysis of TH mRNA. RNAs from mouse E14 embryo striatal cells treated with activin A, bFGF or both were subjected to RNA blot analysis. Upregulation of TH mRNA was evident in bFGF- and activin-treated sample. (D) Expression of TH mRNA in HT22 cells. HT22 cells were cultured in the presence of activin A and/or bFGF for 6, 12 and $24 \mathrm{~h}$, and then evaluated by RT-PCR. (E) The specific bands in panel D were quantified as described for panel B, and the signal intensity of TH mRNA was normalized by that of $\beta$-actin. Each sample was analyzed at least three times, and the difference in the obtained values was always less than $4 \%$. ${ }^{*} P<0 \cdot 01$ vs control; ${ }^{* *} P<0 \cdot 001$ vs activin A- or bFGF-treated cells by $t$-test.

After treatment with activin A and bFGF for $48 \mathrm{~h}$, most of the polygonal cells had changed morphologically with long, elaborate processes, hypertrophic cell bodies, and had developed networks between the cells (Fig. 2A: J-L). When the cells were grown in the presence of bFGF alone, about half the cells displayed the neuron-like morphology (Fig. 2A: G-I). Cells treated with activin A alone, however, did not change their morphology (Fig. 2A: D-F). Regarding the expression of $\mathrm{TH}$ protein, activin A alone had almost no effect (Table 2 and Fig. 2A: D-F). Treatment with activin A and bFGF remarkably increased the number of TH-positive cells (Table 2 and Fig. 2A: J-L), while bFGF alone was less effective (Table 2 and Fig. 2A: G-I) than the cotreatment with activin A. These results were further confirmed by Western blotting. The amount of $\mathrm{TH}$ protein in HT22 cells treated with $100 \mathrm{ng} / \mathrm{ml}$ of activin A and $20 \mathrm{ng} / \mathrm{ml}$ of bFGF for $36 \mathrm{~h}$ was increased ninefold compared with untreated cells (Fig. 2B and C). These results indicate that activin $\mathrm{A}$ and bFGF synergistically induce $\mathrm{TH}$ expression in mouse hippocampal neuronal cells. 
(A)

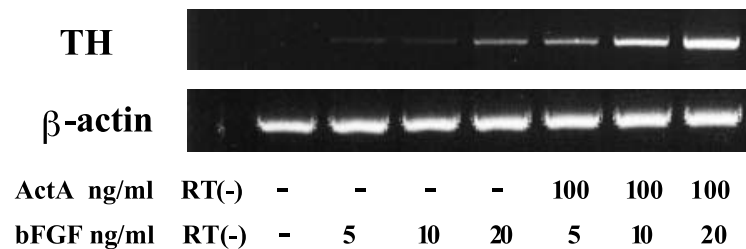

(B)
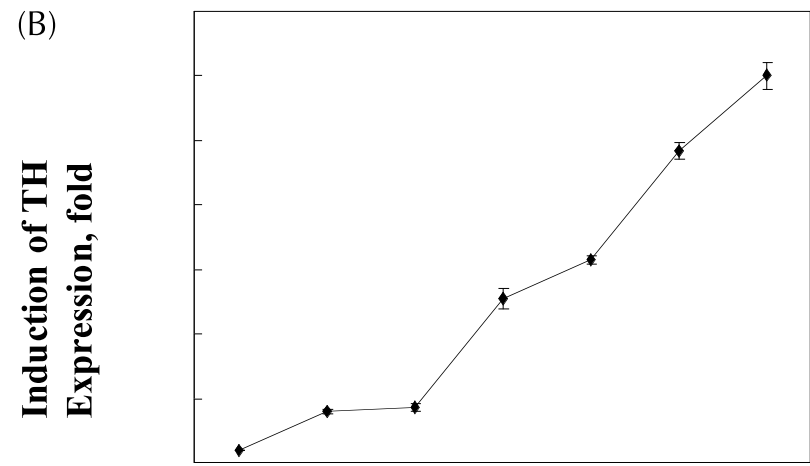

(C)

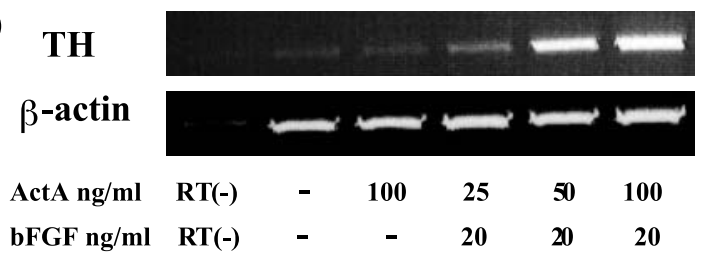

(D)

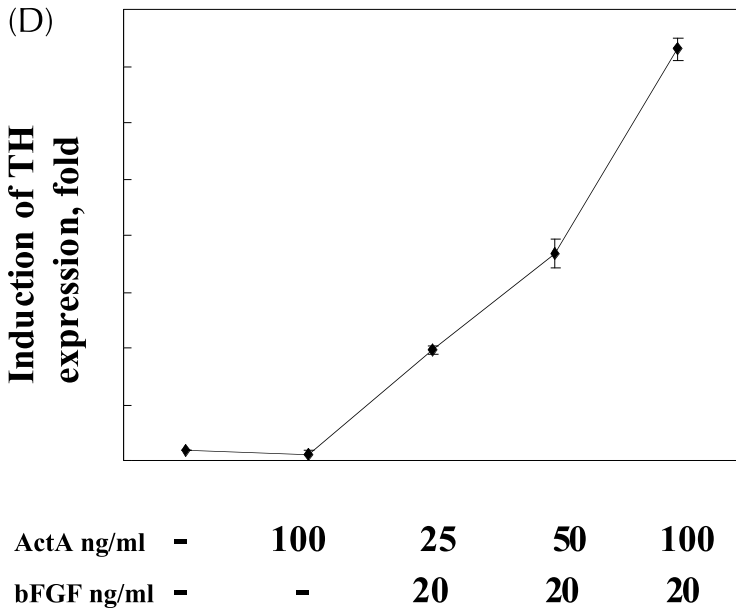

Figure 4 Activin A and bFGF synergistically induce TH mRNA in HT22 cells in a dose-dependent manner. HT22 cells were cultured in the presence of $100 \mathrm{ng} / \mathrm{ml}$ of activin A and increasing concentrations of bFGF (A and B) or in the presence of $20 \mathrm{ng} / \mathrm{ml} \mathrm{bFGF}$ and increasing concentrations of activin A (C and D) for $12 \mathrm{~h}$, and then processed for RT-PCR analysis. The specific bands were quantified as described in the legend for Fig. 3, and the signal intensity of TH was normalized by that of $\beta$-actin. Each sample was analyzed at least three times, and the difference in the obtained values was always less than $5 \%$.

\section{Effect of activin $A$ and bFGF treatment on the expression of endogenous TH $m$ RNA}

To test the possibility that activin A and bFGF directly regulate transcription of the $\mathrm{TH}$ gene, we first analyzed the expression of TH mRNA in mouse striatal cells by RT-PCR. The mRNA of the TH gene was strongly induced by a combination of activin A and bFGF (Fig. 3A and $\mathrm{B})$, and the expression was maintained during the course of the experiment (6-72 h) (data not shown). We further examined the expressions of the AADC and $\mathrm{DBH}$ genes. Like TH, AADC mRNA expression was induced synergistically by a combination of the two factors. Interestingly, DBH was not detected in cultures exposed to activin $\mathrm{A}$ and $\mathrm{bFGF}$, suggesting that the TH-positive neurons were destined to become DA, rather than norepinephrine-producing, cells. We also tested the effect of these two factors on the neuronal cell line HT22. The $\mathrm{TH}$ gene expression was also synergistically induced by cotreatment with activin A and bFGF in the HT22 cell line (Fig. 3C and D). Furthermore, the synergistic effect of activin A and bFGF was dose-dependent for each factor (Fig. 4). To analyze further the transcriptional regulation of the TH gene by activin A and bFGF, we transfected HT22 cells with reporter plasmids containing the fulllength $\mathrm{TH}$ promoter $(4.5 \mathrm{~kb})$ or the proximal promoter
(948 bp), followed by treatment with $100 \mathrm{ng} / \mathrm{ml}$ activin A and/or $20 \mathrm{ng} / \mathrm{ml} \mathrm{bFGF}$ for $12 \mathrm{~h}$. As shown in Fig. 5, activin A alone had no effect on the luciferase activity, while bFGF stimulated the luciferase activity about 1.6-fold for the full-length promoter and 1.9-fold for the proximal promoter compared with the control cells respectively. Cotreatment with activin $\mathrm{A}$ and bFGF enhanced the induction of the TH gene by 2 -fold for the full-length promoter and $3 \cdot 5$-fold for the proximal promoter. The weaker regulation of full-length $\mathrm{TH}$ promoter than that of the proximal promoter reflects the negative and tissue-specific elements on the full-length TH promoter (Sakurada et al. 1999).

\section{Activin $A$ and bFGF activate ERK, but not $p 38$ or JNK, in vitro}

Next, we analyzed the intracellular signaling pathways required for $\mathrm{TH}$ gene activation. To this end, we studied the activation of MAP kinases in mouse primary striatal cells. Activin A and bFGF both induced phosphorylation of ERK1/2 (Fig. 6A and B respectively), and bFGF was more efficient than activin A. Under these conditions, however, a combination of these factors did not further enhance the phosphorylation. Interestingly, activin A, 


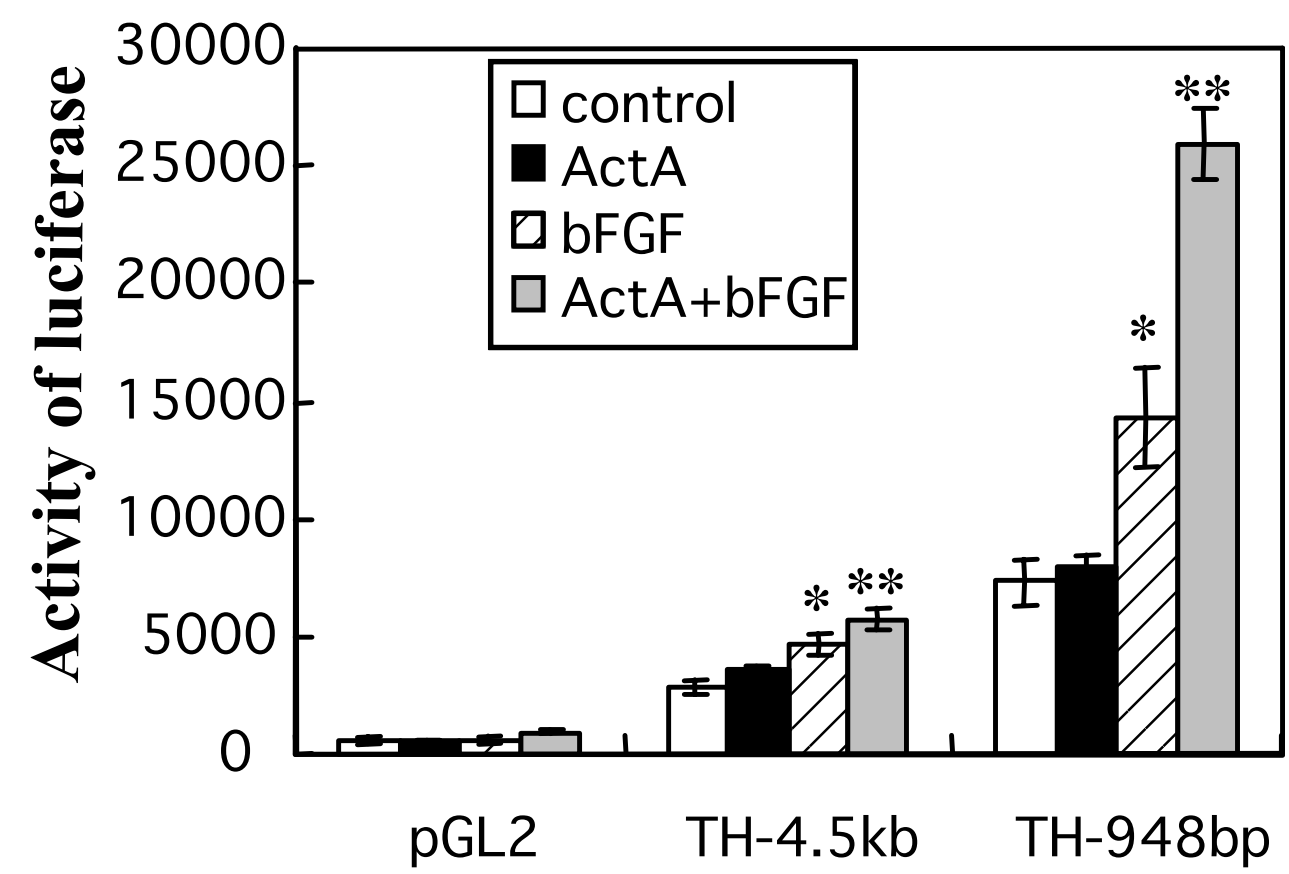

Figure 5 Effects of activin A and bFGF on rat TH promoter activity. HT22 cells were transfected with either TH-4.5 kb-Luc or TH-948 bp-Luc constructs, treated with activin A (100 ng/ml), bFGF (20 ng/ml) or both for $12 \mathrm{~h}$, and then the luciferase activity was measured. The assay was performed in triplicate for each condition. The relative luciferase activity was measured and normalized by the $\beta$-galactosidase activity. ${ }^{*} P<0 \cdot 05$ vs control; ${ }^{*} P<0.05$ vs bFGF-treated cells in TH-4.5 kb, and vs activin A-treated cells in $\mathrm{TH}-948$ bp by $t$-test.

bFGF and their combination all failed to activate either p38 or JNK. Activin A signals through transmembrane receptor serine/threonine kinases to phosphorylate intracellular signaling Smad proteins, which modulate the transcription of the target genes. Activin $\mathrm{A}$ and bFGF stimulated nuclear translocation of Smad3 about 2.5- and $3 \cdot 0-$ fold respectively (Fig. 7A). After treatment with a combination of activin $\mathrm{A}$ and $\mathrm{bFGF}$, the Smad3 in the nuclear fraction was further increased to about sixfold that in the negative control, suggesting that Smad signaling is also activated in this system (Fig. 7B). To determine whether activation of Smad pathway is functionally important, we transfected cDNA for Smad7, an inhibitory Smad, and studied its effect on Smad 3 phosphorylation and $\mathrm{TH}$ promoter activation. Smad7 had an inhibitory effect an Smad 3 phosphorylation induced by activin A and bFGF (Fig. 7C). Furthermore, Smad 7 cDNA interfered with $\mathrm{TH}$ promoter activation by activin $\mathrm{A}$ and bFGF (Fig. 7D). These data indicate the important role of the Smad signaling pathway for $\mathrm{TH}$ regulation by activin A and bFGF.

Activation of ERK1/2 MAPK is required for the synergistic effect of activin $A$ and bFGF on induction of the TH gene

To investigate whether ERK activation is involved in the induction of the TH gene by activin $\mathrm{A}$ and bFGF, we analyzed the effect of a MAPK inhibitor on the induction of the TH promoters, using luciferase assays. U0126, a specific inhibitor for MEK, completely inhibited the activin A- or bFGF-dependent phosphorylation of the MEK substrates ERK1/2, whereas treatment with a specific inhibitor for phosphatidylinositol-3 kinase (PI3K), LY294002, did not affect the activation of ERK1/2 (Fig. 8A). When HT22 cells were treated with U0126, activation of the $\mathrm{TH}$ promoter by activin $\mathrm{A}$ and bFGF was strongly impaired (Fig. 8B). Similar inhibition was observed when another MEK inhibitor, PD98059, was used. In contrast, a p38 inhibitor, SB203580, or LY294002, had no effect on the TH promoter activity regardless of the presence or absence of activin A and/or bFGF. These results indicate that activation of ERK1/2 is required for the $\mathrm{TH}$ gene transcription induced by bFGF and/or activin A in HT22 cells.

\section{Discussion}

Parkinson's disease is a common neurodegenerative disorder that involves progressive disability, rigidity and tremors. Several strategies, including stereotaxic brain lesions, deep brain stimulation, transplants of DA cells and administration of neurotrophic factors, have been proposed to improve efficacy and counteract progression of 


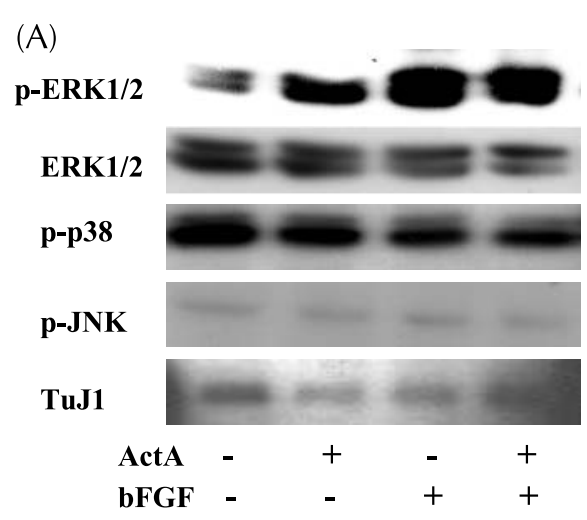

(B)

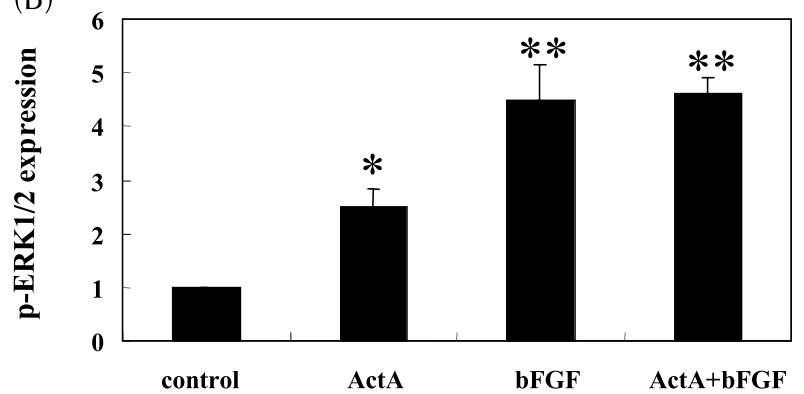

Figure 6 Western blotting analysis of ERK $1 / 2$ phosphorylation in mouse E14 striatal cells. (A) Mouse primary striatal cells were cultured in six-well tissue culture plates, and treated with activin A $(100 \mathrm{ng} / \mathrm{ml})$, bFGF $(20 \mathrm{ng} / \mathrm{ml})$ or both for $45 \mathrm{~min}$, and then whole-cell lysates were subjected to Western blotting with the indicated antibodies. (B) Bar graph shows the combined signal of the p-ERK1/2 bands assessed with NIH Image 1.62 software and normalized by the TuJ 1 signal. Expression of p-ERK $1 / 2$ in control cells was normalized to 1.0 in the figure. ${ }^{*} P<0.05$ vs control; ${ }^{* *} P<0 \cdot 05$ vs activin A treated cells by $t$-test.

the disease. The generation of DA neurons is the most important. $\mathrm{TH}$ is the major rate-limiting enzyme of catecholamine biosynthesis in DA and noradrenergic neurons (Nagatsu et al. 1964). Accordingly, the expression of $\mathrm{TH}$ plays a crucial role in regulating the level of catecholamines in the brain and periphery. Regulation of $\mathrm{TH}$ expression has been shown to be complex in various neuronal lineages (Sabban 1997), and neurotrophic factors, glucocorticoids, retinoic acid and synaptic activities, as well as various reagents and hormones that elevate cAMP, have been shown to increase $\mathrm{TH}$ expression in cultured cells and tissues (Nagatsu 1995).

The neuroprotective and neurotrophic roles of bFGF are well documented. A recent study revealed that bFGF strongly enhances lesion-associated induction of activin A, indicating that activin acts downstream of bFGF in the hippocampus (Tretter et al. 2000). Several groups have previously reported that bFGF influences $\mathrm{TH}$ gene expression. Synergistic interaction of neurotransmitters and coactivators such as bFGF induces the expression of
$\mathrm{TH}$ in the neurons of the developing striatum ( $\mathrm{Du} \&$ Iacovitti 1995). In contrast, it is reported that bFGF produces the recovery of motor behavior, dopamine metabolite levels, striatal F-DOPA uptake and THpositive cells in hemiparkinsonian monkeys (Fontan et al. 2002). However, although the number of striatal THpositive cells was higher in the group of animals treated with bFGF than in the other groups, the differences were not significant, suggesting that bFGF alone is not sufficient. The important finding of the current study is that activin A and bFGF can synergistically induce the expression of $\mathrm{TH}$ at both the protein and mRNA levels. Furthermore, we showed that activin A and bFGF show a synergistic effect to induce $\mathrm{TH}$ promoter activity, indicating that the induction is mediated transcriptionally. However, activin A alone did not appear to modify the expression of $\mathrm{TH}$, suggesting that activin A may act as an instructive regulator of bFGF actions on striatal cells. Our findings provide evidence that activin $\mathrm{A}$ influences the developmental potential of neuronal progenitors, whereas bFGF could trigger the differentiation of new TH-positive neurons from neuronal progenitors, and they support the hypothesis that combinatorial signaling may operate at the early stages of neuronal development to specify their fate. Our results are also promising with regard to the possibility of developing new strategies for neuroprotection.

Catecholamines are synthesized from a common cellular metabolite, tyrosine, by three major enzymes: TH, AADC and $\mathrm{DBH}$. In this study, we detected consistent upregulation of $\mathrm{TH}$ and AADC mRNAs without detectable $\mathrm{DBH}$ mRNA (Fig. 3A). Since DBH is specifically expressed in adrenergic neurons (Tiveron et al. 1996, Krieglstein et al. 1998), these data suggest that the $\mathrm{TH}$-positive neurons induced by activin $\mathrm{A}$ and bFGF are likely to be DA, rather than adrenergic or noradrenergic.

Activin $\mathrm{A}$ is a multifunctional factor that regulates a variety of cellular processes, including proliferation, apoptosis, production of extracellular matrix and differentiation (Chen et al. 2002). It is well known that Smad2/Smad3 are the downstream signaling mediators of activin $\mathrm{A}$ (Chen et al. 2002, Tsuchida 2004). We observed that activin A and bFGF increased the Smad3 protein level in the nuclei of HT22 cells. Our results suggest that activin A and bFGF can activate translocation of Smad3 into nuclei and that the Smad3 signaling pathway may be involved in the synergistic effect of activin A and bFGF on TH expression.

The most important finding of the current study is the critical role of Smad 3 and ERK1/2 in mediating the signals contributing to the TH-positive neuronal differentiation induced by activin A and bFGF. Previous reports have suggested that MAPK may be a player in TH expression. TH-inducing pathways, including PKA or PKC activators as well as dopamine (acting via the D1/D5 receptor) and FGF, have been shown to result in the phosphorylation of MAPK (Ray \& Sturgill 1988, Ahn et al. 1990, Gomez et al. 1990, L'Allemain et al. 1991, 
(A)

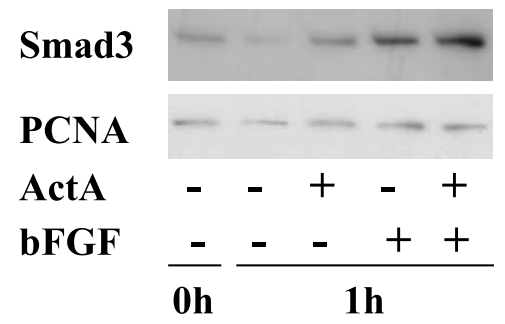

(B)

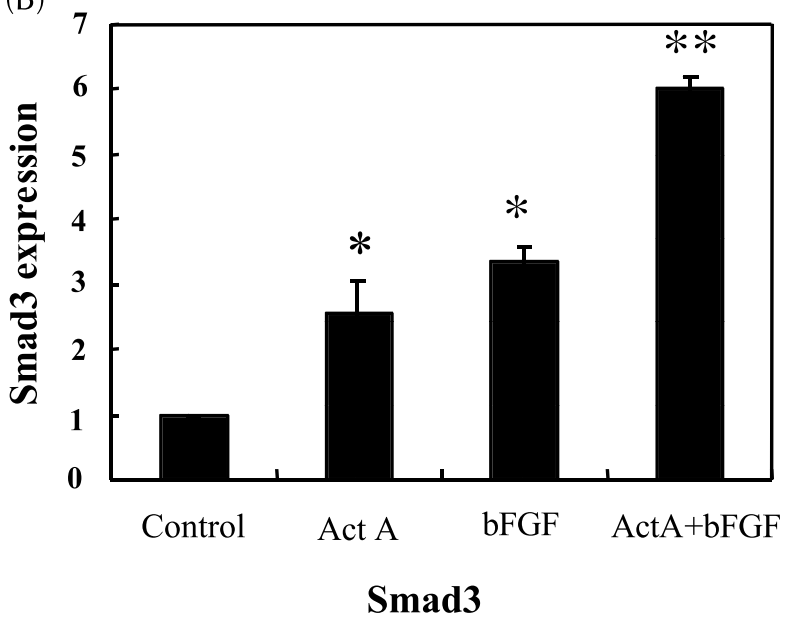

(C)

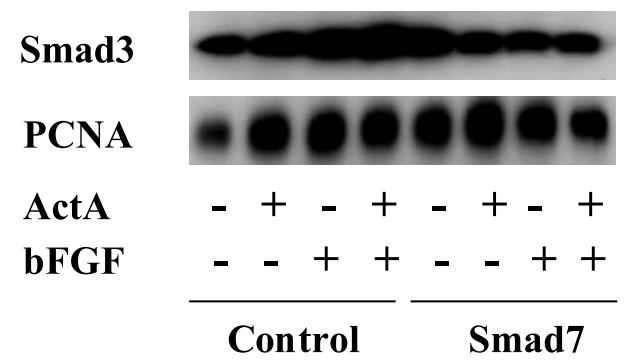

(D)

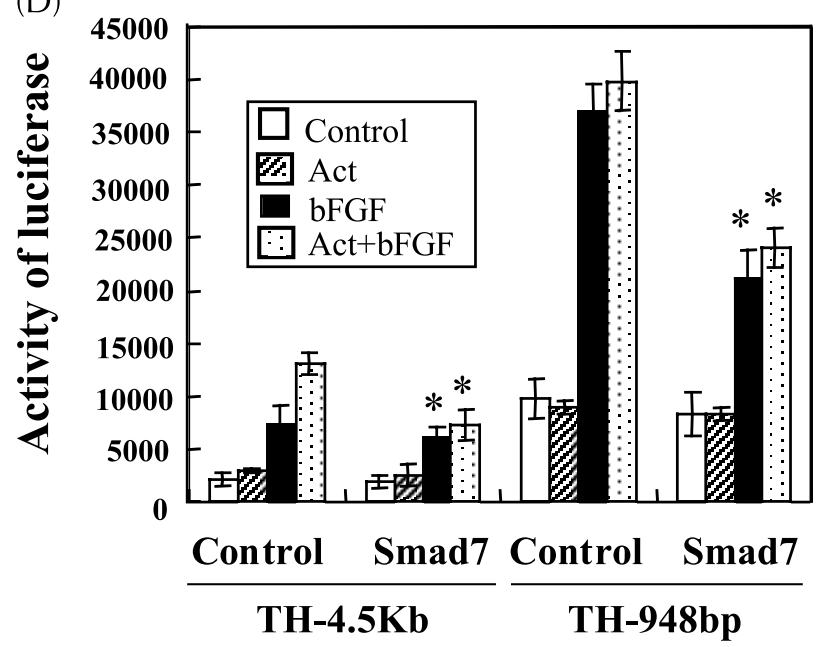

Figure 7 Effect of activin A and bFGF on the activation of Smad3. (A) HT22 cells were cultured in medium alone or medium containing activin $\mathrm{A}(100 \mathrm{ng} / \mathrm{ml})$, bFGF $(20 \mathrm{ng} / \mathrm{ml})$ or both for $1 \mathrm{~h}$, and then nuclear extracts were subjected to Western blotting analysis with antibodies against Smad3 and PCNA. (B) The specific bands for Smad3 were quantified with NIH Image 1.62 software and normalized by the anti-PCNA signal. Expression of Smad3 in control cells was normalized to $1 \cdot 0$ in the figure. ${ }^{*} P<0 \cdot 01$ vs control; ${ }^{* *} P<0 \cdot 01 \mathrm{vs}$ activin A- or bFGF-treated cells by t-test. (C) HT22 cells were either mock transfected or transfected with cDNA for Smad7, and cultured in medium without or with activin A $(100 \mathrm{ng} / \mathrm{ml})$ and bFGF $(20 \mathrm{ng} / \mathrm{ml})$, and subjected to Western blotting analysis as described for panel A. (D) HT22 cells were transfected with TH-promoter construct without or with cDNA for Smad7, and subjected to luciferase analysis. The assay was performed in triplicate for each condition. The relative luciferase activity was measured and normalized by the $\beta$-galactosidase activity. ${ }^{*} P<0 \cdot 05$ vs control in each group by t-test.

Sutherland et al. 1993, Zhan et al. 1994). Among several MAPKs, ERK is known to be important in the regulation of TH activity (Yamauchi \& Fujisawa 1979, Albert et al. 1984, Vulliet et al. 1984, Campbell et al. 1986, Haycock et al. 1992, Sutherland et al. 1993, Halloran \& Vulliet 1994). In this study, we found that phosphorylation of ERK1/2 was increased after the cells were treated with activin $\mathrm{A}$ and bFGF. ERK1/2 was also activated by bFGF alone, but only very weakly by activin A. Our data further suggest that the $\mathrm{TH}$ gene expression induced by activin A and bFGF is dependent on the Smad signaling pathway, but not on the PI3 kinase pathway. These results suggest that the synergistic effect of activin A and bFGF on TH expression is due to cross-talk between the Smad and ERK signaling pathways.

In conclusion, we have demonstrated, for the first time, that activin A acts synergistically with bFGF to induce TH expression through the Smad and ERK pathways in both striatal and HT22 cells. This novel mechanism of TH promoter regulation may provide a useful basis for understanding the in vivo regulation of $\mathrm{TH}$ gene expression during development as well as in certain physiologic conditions. Our findings elucidate one type of mechanism by which cellular diversity in the developing brain could be augmented, and may also be useful for generating therapeutic approaches to neurodegenerative disorders. Identification of the environmental cues directing the fate of these neural precursors could provide a means to generate expandable, well-defined neural cell populations for reconstructive transplant strategies or to stimulate directly the ability of the brain to repair itself.

\section{Acknowledgements}

We thank Dr Schubert (Salk Institute, La Jolla, CA, USA) for HT22 cells and Dr D Chikaraishi (Duke University 
(A)
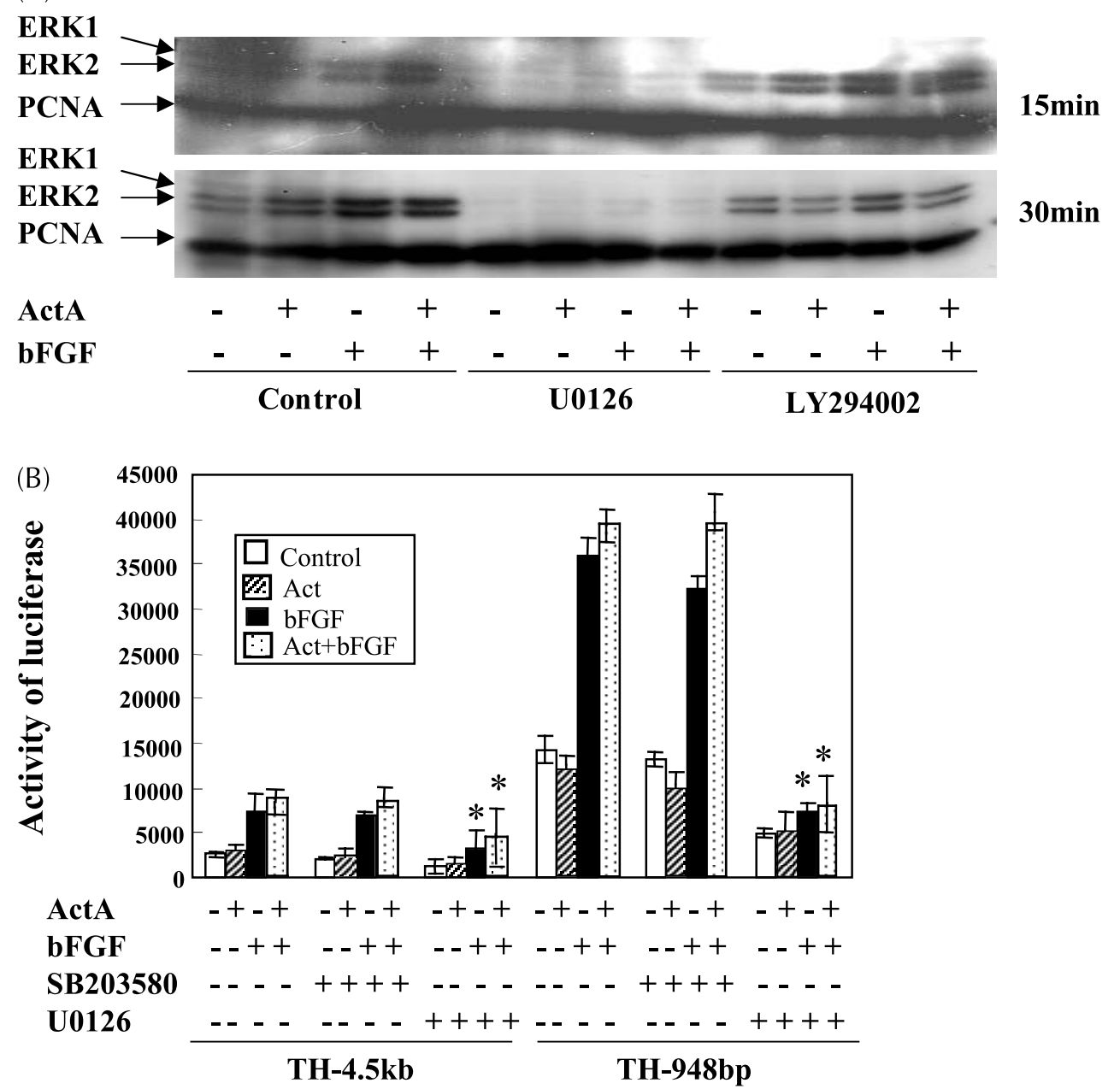

Figure 8 Effect of MAP kinase inhibitors on the ERK1/2 activation (A) and TH gene expression (B) induced by activin A and bFGF. (A) HT22 cells were exposed to activin A $(100 \mathrm{ng} / \mathrm{ml})$, bFGF $(20 \mathrm{ng} / \mathrm{ml})$ or both in the presence of $\mathrm{U} 0126(10 \mu \mathrm{M})$ or LY294002 $(10 \mu \mathrm{M})$ for 15 or 30 min respectively. Nuclear extracts were then prepared and subjected to Western blotting analysis. (B) HT22 cells were transfected with TH-4-5-Luc or TH-948-luc reporter plasmids. Twenty-four hours later, the inhibitor SB203580 (10 $\mu \mathrm{M})$ or U0126 was added 5 min before the activin A and bFGF treatment. The luciferase activity was analyzed $6 \mathrm{~h}$ after the ligand addition. The assay was performed in triplicate for each condition. The relative luciferase activity was measured and normalized by the $\beta$-galactosidase activity. ${ }^{*} P<0 \cdot 01$ compared with TH promoter activities without inhibitor treatment by $t$-test.

Medical School, Durham, NC, USA) for the rat $\mathrm{TH}$ promoter construct.

\section{Funding}

This research was supported by the Ministry of Education, Science, Sports, Culture and Technology of Japan (grants to $\mathrm{K} \mathrm{T}$ and $\mathrm{H} \mathrm{S}$ ) and also by a grant from the Ministry of Health, Labour and Welfare to K T. The authors declare that there is no conflict of interest that would prejudice the impartiality of this scientific work.

\section{References}

Ahn NG, Weiel JE, Chan CP \& Krebs EG 1990 Identification of multiple epidermal growth factor-stimulated protein serine/threonine kinases from Swiss 3 T3 cells. Journal of Biological Chemistry 265 11487-11494.

Albert KA, Helmer-Matyjek NE, Nairn AC, Muller TH, Haycock JW, Greene LA, Goldstein M \& Greengard P 1984 Calcium/ phospholipid-dependent protein kinase (protein kinase C) phosphorylates and activates tyrosine hydroxylase. PNAS $\mathbf{8 1}$ 7713-7717.

Cameron VA, Nishimura E, Mathews LS, Lewis KA, Sawchenko PE \& Vale WW 1994 Hybridization histochemical localization of activin receptor subtypes in rat brain, pituitary, ovary and testis. Endocrinology 134 799-808. 
Campbell DG, Hardie DG \& Vulliet PR 1986 Identification of the four phosphorylation sites in the N-terminal region of tyrosine hydroxylase. Journal of Biological Chemistry 261 10489-10492.

Chen YG, Lui HM, Lin SL, Lee JM \& Ying SY 2002 Regulation of cell proliferation, apoptosis, and carcinogenesis by activin. Experimental Biology Medicine (Maywood) 227 75-87.

Claus P, Werner S, Timmer M \& Grothe C 2004 Expression of the fibroblast growth factor-2 isoforms and the FGF receptor 1-4 transcripts in the rat model system of Parkinson's disease. Neuroscience Letters 360 117-120.

Du X \& Iacovitti L 1995 Synergy between growth factors and neurotransmitters required for catecholamine differentiation in brain neurons. Journal of Neuroscience 15 5420-5427.

Ehringer H \& Hornykiewicz O 1960 Distribution of noradrenaline and dopamine (3-hydroxytyramine) in the human brain and their behavior in diseases of the extrapyramidal system. Klinische Wochenschrift 38 1236-1239.

Fann MJ \& Patterson PH 1994a Depolarization differentially regulates the effects of bone morphogenetic protein (BMP)-2, BMP-6 and activin A on sympathetic neuronal phenotype. Journal of Neurochemistry 63 2074-2079.

Fann MJ \& Patterson PH 1994b Neuropoietic cytokines and activin A differentially regulate the phenotype of cultured sympathetic neurons. PNAS 91 43-47.

Fontan A, Rojo A, Sanchez Pernaute R, Hernandez I, Lopez I, Castilla C, Sanchez Albisua J, Perez Higueras A, Al-Rashid I, Rabano A, Gonzalo I, Angeles Mena M, Cools A, Eshuis S, Maguire P, Pruim J, Leenders K \& Garcia de Yebenes J 2002 Effects of fibroblast growth factor and glial-derived neurotrophic factor on akinesia, F-DOPA uptake and dopamine cells in parkinsonian primates. Parkinsonism and Related Disorders $\mathbf{8}$ 311-323.

Funaba M, Murata T, Fujimura H, Murata E, Abe M \& Torii K 1997 Immunolocalization of type I or type II activin receptors in the rat brain. Journal of Neuroendocrinology 9 105-111.

Gomez N, Tonks NK, Morrison C, Harmar T \& Cohen P 1990 Evidence for communication between nerve growth factor and protein tyrosine phosphorylation. FEBS Letters 271 119-122.

Grothe C, Schulze A \& Semkova I 2000 The high molecular weight fibroblast growth factor-2 isoforms $(21000$ and $23000 \mathrm{~mol}$. wt) mediate neurotrophic activity on rat embryonic mesencephalic dopaminergic neurons in vitro. Neuroscience 100 73-86.

Gudmundsson KR 1967 A clinical survey of parkinsonism in Iceland. Acta Neurologica Scandinavica 33 (Suppl) 1-61.

Halloran SM \& Vulliet PR 1994 Microtubule-associated protein kinase-2 phosphorylates and activates tyrosine hydroxylase following depolarization of bovine adrenal chromaffin cells. Journal of Biological Chemistry 269 17430-17440.

Haycock JW, Ahn NG, Cobb MH \& Krebs EG 1992 ERK1 and ERK2, two microtubule-associated protein kinases, mediate the phosphorylation of tyrosine hydroxylase at serine 31 in situ. PNAS $892365-2369$.

Hughes PE, Alexi T, Williams CE, Clark RG \& Gluckman PD 1999 Administration of recombinant human activin-A has powerful neurotrophic effects on select striatal phenotypes in the quinolinic acid lesion model of Huntington's disease. Neuroscience $\mathbf{9 2}$ 197-209.

Krieglstein K, Reuss B, Maysinger D \& Unsicker K 1998 Transforming growth factor- $\beta$ mediates the neurotrophic effect of fibroblast growth factor-2 on midbrain dopaminergic neurons. European Journal of Neuroscience 10 2746-2750.

L'Allemain G, Sturgill TW \& Weber MJ 1991 Defective regulation of mitogen-activated protein kinase activity in a $3 \mathrm{~T} 3$ cell variant mitogenically nonresponsive to tetradecanoyl phorbol acetate. Molecular and Cellular Biology 11 1002-1008.
Lewen A, Soderstrom S, Hillered L \& Ebendal T 1997 Expression of serine/threonine kinase receptors in traumatic brain injury. NeuroReport 8 475-479.

Mathews L 1994 Activin receptors and cellular signaling by the receptor serine kinase family. Endocrine Reviews 15 310-325.

Nagatsu T 1995 Tyrosine hydroxylase: human isoforms, structure and regulation in physiology and pathology. Essays in Biochemistry 30 $15-35$.

Nagatsu T, Levitt M \& Udenfriend S 1964 Tyrosine hydroxylase; the initial step in norepinephrine biosynthesis. Journal of Biological Chemistry 239 2910-2917.

Ray LB \& Sturgill TW 1988 Insulin-stimulated microtubule-associated protein kinase is phosphorylated on tyrosine and threonine in vivo. PNAS 85 3753-3757.

Roberts VJ, Sawchenko PE \&Vale W 1991 Expression of inhibin/activin subunit messenger ribonucleic acids during rat embryogenesis. Endocrinology 128 3122-3129.

Sabban EL 1997 Control of tyrosine hydroxylase gene expression in chromaffin and PC12 cells. Seminars in Cell and Developmental Biology 8 101-111.

Sakurada K, Ohshima-Sakurada M, Palmer TD \& Gage FH 1999 Nurr1, an orphan nuclear receptor, is a transcriptional activator of endogenous tyrosine hydroxylase in neural progenitor cells derived from the adult brain. Development 126 4017-4026.

Schubert D, Kimura H, LaCorbiere M, Vaughan J, Karr D \& Fischer WH 1990 Activin is a nerve cell survival molecule. Nature 344 868-870.

Shoji H, Tsuchida K, Kishi H, Yamakawa N, Matsuzaki T, Liu Z, Nakamura T \& Sugino H 2000 Identification and characterization of a PDZ protein that interacts with activin type II receptors. Journal Biological Chemistry 275 5485-5492.

Sutherland C, Alterio J, Campbell DG, LeBourdelles B, Mallet J, Haavik J \& Cohen P 1993 Phosphorylation and activation of human tyrosine hydroxylase in vitro by mitogen-activated protein (MAP) kinase and MAP-kinase-activated kinases 1 and 2. European Journal of Biochemistry 217 715-722.

Tiveron MC, Hirsch MR \& Brunet JF 1996 The expression pattern of the transcription factor Phox2a delineates synaptic pathways of the autonomic nervous system. Journal of Neuroscience 16 7649-7660.

Tretter YP, Hertel M, Munz B, ten Bruggencate G, Werner S \& Alzheimer C 2000 Induction of activin A is essential for the neuroprotective action of basic fibroblast growth factor in vivo. Nature Medicine 6 812-815.

Tsuchida K 2004 Activins, myostatin and related TGF- $\beta$ family members as novel therapeutic targets for endocrine, metabolic and immune disorders. Current Drug Targets, Immune, Endocrine and Metabolic Disorders 4 157-166.

Vulliet PR, Woodgett JR \& Cohen P 1984 Phosphorylation of tyrosine hydroxylase by calmodulin-dependent multiprotein kinase. Journal of Biological Chemistry 259 13680-13683.

Yamauchi T \& Fujisawa H 1979 Regulation of bovine adrenal tyrosine-3-monooxygenase by phosphorylation-dephosphorylation reaction, catalyzed by adenosine $3^{\prime}, 5^{\prime}$-monophosphate-dependent protein kinase and phosphoprotein phosphatase. Journal of Biological Chemistry 254 6408-6413.

Zhan X, Plourde C, Hu X, Friesel R \& Maciag T 1994 Association of fibroblast growth factor receptor-1 with c-Src correlates with association between c-Src and cortactin. Journal of Biological Chemistry 269 20221-20224.
Received 24 November 2004
Accepted 8 December 2004
Made available online as an
Accepted Preprint 9 December 2004 